\title{
ÖSSZEHASONLÍTÓ TANULMÁNY EGY HÁROMSZÖG RÁCSOS GEOSZINTETIKUS ANYAGOKKAL MEGERŐSÍTETT ÚTSZAKASZ VALÓS ÉS VIRTUÁLIS MODELLEZÉSE KAPCSÁN
}

\section{COMPARATIVE STUDY ON NUMERICAL AND FULL SCALE MODELING OF A ROAD STRUCTURE REINFORCED WITH TRIAXIAL GEOGRIDS}

\author{
Nagy Andor-Csongor ${ }^{1}$, Ursu Ivett ${ }^{2}$, Moldovan Dorin ${ }^{3}$ \\ Kolozsvári Müszaki Egyetem, Epitömérnöki kar, Tartószerkezet Tanszék, 400027, \\ Románia, Kolozsvár, G. Bariţiu utca, 25. szám; \\ landor.nagy@yahoo.com \\ 2 ursuivett@gmail.com \\ 32dorin.moldovan@dst.utcluj.com
}

\begin{abstract}
The current trend in the construction design and execution leans toward environmentally friendly solutions. Most of the research activity is oriented by innovations, which lead to unusual combinations of conventional building materials with alternative materials. Such a combination can be obtained by reinforcing earth fillings with plastic materials, in the form of a triangular meshed grid. The earthgeosynthetic aggregate is highly enduring, because the plastic material isn't subjected to environmental conditions that usually facilitate its degradation, thus retains its original flexibility, and effectively acts as a steel bar reinforcement of the reinforced concrete element.
\end{abstract}

Keywords: triaxial geogrid, finite element modeling, Lucas plate test.

\section{Összefoglalás}

Az építőipar jelenlegi trendje a környezetbarát megoldások felé hajlik. Aktuális kutatások jelszava az „innováció”, aminek közvetlen következménye a klasszikus épitőanyagok szokatlan kombinációja alternatív anyagokkal. Egy ilyen párosítás az alapozási talaj megerősítése műanyagból készült hálószerkezetekkel. A föld-geoszintetikus kombináció kifejezetten tartós megoldás, mert a műanyagot nem érik azon környezeti körülmények amelyek elősegítik az „öregedési” folyamatot, így megtartja eredeti rugalmasságát, és gyakorlatilag úgy müködik, akár a vasalás egy vasbeton elemben.

Kulcsszavak: háromszög rácsos geoszintetikus háló, véges elem modellezés, Lucas lemez teszt. 


\section{Bevezetés. A dolgozat korszerü- ségének indoklása.}

Kutatásaink során egy különleges helyzetet tanulmányoztunk geoszintetikus hálóval erősített útszerkezetek esetében. Bizonyos külső és belső elemek hatására (pl. rezgések, talajvíz áramlás) az alapozási talajban kissebb-nagyobb méretü rések, hézagok keletkezhetnek. Legtöbbször a felszínen semmi jel nem utal a mélyben keletkezett ürre, de rövidebb vagy hosszabb távon a rések kiterjednek, belső kráterekké alakulnak (az okozó elemek folyamatos hatása alatt), majd váratlanul bekövetkezik a felszín beomlása. Ilyen jellegü hézagok előfordulása elég gyakori jelenség, a kiváltó okok sokoldalúsága miatt. Keletkezhetnek karsztikus régiók talajvíz áramlása során, belvárosi csővezetékek meghibásodásából, vagy dinamikus terhelés miatt, aminek oka lehet a közlekedés vagy földrengés. Felmerül a kérdés, hogyan viselkedne egy geoszintetikus hálóval megerősített szerkezet egy hézagos talaj felett?

Romániában, 2013 őszén, a Galac megyében található Izvoarele község területén, máig ismeretlen okokból, október - december periódusban több mint 300 kis és közepes méretü földrengés történt (2,5 4 intenzitással a Richter skálán), aminek következtében különbözö méretü kráterek, és süppedések keletkeztek a régioban, utak hasadtak szét, házak omlottak össze, és több család került áttelepítésre. Természetesen, nehéz előrelátni és számolni ilyen helyzetekkel, a javítási költségek pedig jelentősek. Ezért épitéstudományi, társadalmi és gazdasági jelentőséggel bír a fenti kérdés megválaszolása.

\section{Laboratóriumi és virtuális mo- dellek létrehozása}

A tanulmány két irány szerint haladt: egyrészt létrehoztunk egy 1:1 méretarányban készült laboratóriumi modellt, amin egy hézaggal ellátott útszakasz viselkedését elemeztük normális közlekedési viszonyok alatt, majd tanulmányunk második részében ugyanezt a modellt létrehoztuk egy véges elem modellezési programban (GFAS) is az eredmények összehasonlításának céljából.

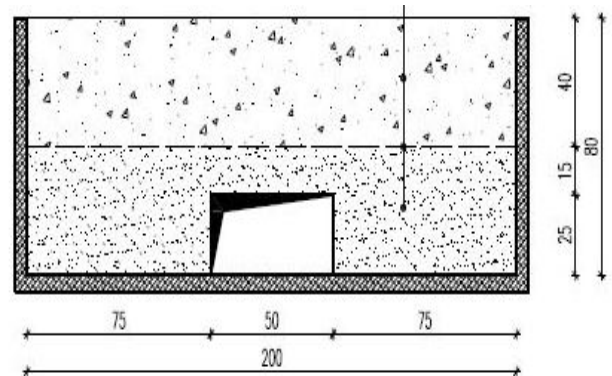

1. ábra. A laboratóriumi modell konfigurálása és méretei

A kísérleti modelleket egy dobozban éptettük fel, amelynek méretei a következőek voltak: 1.50 méter szélesség, 1.00 méter magasság, és $1.00 \mathrm{~m}$ hosszúság, az 1. ábra szerint. A tanulmányozott útszakasz alapját egy $40 \mathrm{~cm}$ vastagságú agyagréteg képezte, a második réteg pedig, ami szintén $40 \mathrm{~cm}$ vastag volt, zúzott kőből készült. A doboz alsó részén, a szélesség közepén létrehoztuk az $50 \mathrm{~cm}$ széles és $25 \mathrm{~cm}$ magas hézagot. A hézag jelenléte a bevezetésben volt megindokolva

A Lucas lemez teszt során meghatározzuk az adott útszerkezet lineáris alakváltozási moduluszát (a Young moduluszt). A tesztelési folyamat abból állt hogy egy 300 $\mathrm{mm}$ átméröjű merev fém lemezt terheltünk statikusan $50 \mathrm{kPa}$ nyomástól kezdve, további $50 \mathrm{kPa}$-nyi lépésekben haladva egészen a struktúra töréséig, folyamatosan követve a felületi süppedést (15 percenként leolvastuk az értékeket a lemez felületén elhelyezett 3 mérőmüszerről). A következő terhelési lépést csak abban az esetben aplikálhattuk, ha a felületi deformáció stabilizáltnak számított (vagyis 30 percen keresztül nem süppedt több mint $0.1 \mathrm{~mm}-\mathrm{t}$ az utolsó olvasott 

megerösitett útszakasz valós és virtuális modellezése kapcsán

értékhez viszonyítva) [1]. A Lucas lemezt a modell szélességének közepén helyeztük el, a hézag felett, így a lehetö legkedvezötlenebb terhelési forgatókönyvet követhettük nyomon.

\section{A geoszintetikus anyag szerepe. Háromszögrácsos geoháló.}

A gyakorlatban felhasznált geoszintetikus elemek egy vagy kétdimenziósak, a legközönségesebb a háló formájában gyártott, négyzet és háromszögnyílással ellátott geohálók. A szokványos földkonszolidáció munkálatok nagy mennyiségü kőfejtő aggregátumot, cementet, vasalást igényelnek. Ezzel összevetve a geoszintetikusháló gyártása megvalósítható akár újrahasznosított müanyagból is, gyakorlatilag bármilyen aggregátummal múködőképes, beépítése pedig nem igényel nagyobb gépmunkát, mivel szőnyegként szétterítik, majd ráhelyezik a földtöltést és tömörítik.

A háromszög a legstabilabb mértani forma (bármilyen torzulása szintén háromszögformát eredményez). A háromszögrácsos geoháló magas radiális merevséggel rendelkezik, aminek köszönhetően egységesen oszlik el a közlekedési terhelésböl származó nyomás kúp, így egyértelmủ választás volt a kísérlet számára [2].

\section{A véges elem modellezés mód- szer aplikálása az adott kísér- letben}

A véges elem módszerrel végzett modellezés megfelelő a virtuális modell kialakításához, mert létrehozható benne a föld-geoszintetikus kölcsönhatás. Ugyanakkor a struktúra törése modellezhetö talajvíztől függő vagy független körülmények között, ami az adott modell esetében kifejezetten fontos, tekintve hogy kohezív és nem kohezív földszerkezeti típusokat használtunk fel (agyag és zúzott kö).
A véges elem modellezés meghatároz minden aplikált terhelésnek egy megfelelö feszültségi mezöt. Egy adott törési kritérium segítségével a program kimutatja, ha a bevezetett struktúra valamelyik pontjában fellép a törés. A törési kritériumok meghatározzák egy adott anyag lineáris - rugalmassági korlátait. Modellünk számára az ideális törési kritérium a von Mises volt, mivel a felhasznált földtípusok magas nedvességgel rendelkeztek. Ezen törési kritérium alapfeltevése hogy a maradandó alakváltozás akkor következik be, amikor a deformációhoz szükséges potenciális energia $\left(W_{d}\right)$ elér egy kritikus értéket (minden bevezetett anyagra külön jellemzö) [3], [4]:

$$
W_{d}=\frac{1+v}{6 E}\left[\left(\sigma_{1}-\sigma_{2}\right)^{2}+\left(\sigma_{2}+\sigma_{3}\right)^{2}+\left(\sigma_{3}+\sigma_{1}\right)^{2}\right]
$$

ahol E a Young modulusz, $v$ a Poisson hányadós, $\sigma_{1}, \sigma_{2}$ és $\sigma_{3}$ pedig az „x”, „y” és „Z" irányra fuggőleges feszültségek.

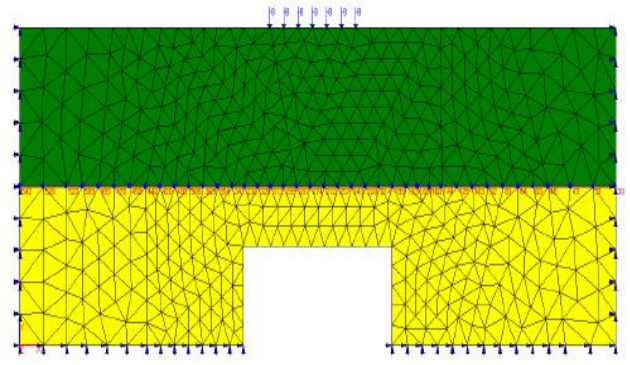

2. ábra. A GFAS programban létrehozott számítási modell

\section{Valós és virtuális modell visel- kedése adott terhelés alatt. Ösz- szehasonlítás}

A valós és virtuális modellek feltünően hasonlóan viselkedtek alakváltoztatás és tartóképesség szempontjából, amint a 3 . ábra is mutatja. A laboratóriumi modell 800 kPa-nak megfelelő nyomás alatt vesztette el 
tartóképességét, míg a GFAS véges elem modellezési programban létrehozott útszakasz keresztmetszet esetében $750 \mathrm{kPa}$ nyomás esetében következett be a törés.

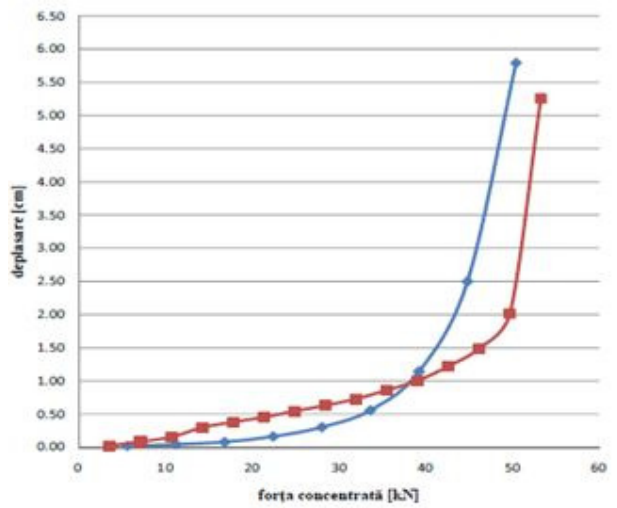

3. ábra. Laboratóriumi (piros) és számitógépes modell (kék) viselkedése felületi süppedés - aplikált nyomás függvényében

A törés pillanatában mért maximális felületi alakváltozás esetében sincs nagy különbség a két modell között, a laboratóriumban $5.30 \mathrm{~cm}$-t mértünk, míg a számítógépes modell $5.75 \mathrm{~cm}$-t mutatott ki.

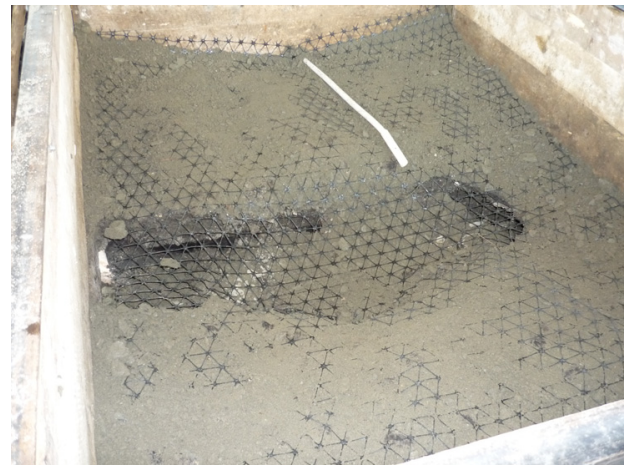

4. ábra. Az elszakadt háromszögrácsos geoháló a laboratóriumban tesztelt modell belsejében

\section{Következtetések}

A tanulmány egy különleges eset kétféle megközelítését mutatja be. Kiindulópontunk egy valóságban előforduló hézagos útszakasz volt. A stabilizálás érdekében modern, geoszintetikus anyaggal erősítettük meg struktúránkat. Összevetve a valós és virtuális modell tesztelése során elért eredményeket:

- a törési kritérium megfelelő megválasztása esetén a számítógépen létrehozott modell rendkívül hasonló módon viselkedik, mint a valóságban létrehozott modell;

- a felületi süppedések szinte azonosak a két modellben, ugyanakkor hasonló a variációjuk is az aplikált nyomás függvényében;

- a kisebb eltérések a véges elem modellezés alapkövetelményéből származnak, ami szerint a diszkretizált elemek folyamatosan érintkezésben vannak, ez a valóságban nem feltétlenül van így.

\section{Szakirodalmi hivatkozások}

[1] STAS 2914/4-89 Lucrări de drumuri şi căi ferate. Determinarea modulului de deformaţie liniară prin încercări pe teren cu placa.

[2] Iliescu, M: Geosintetice, Ed. Dacia, ClujNapoca, 1994

[3] Chiorean, C: Calculul neliniar al structurilor vol. 1, U.T. Press, Cluj-Napoca, 2009

[4] Chiorean, C: Geostru software, GFAS Finite Element Systems for Geotechnical applications, Theoretical and User Manual 2010, www.geostru.com 